\title{
Otel İşletmelerine Yönelik E-Şikâyetlerin İçerik Analizi ile İncelenmesi: Kuşadası 5 Yıldızlı Otel İşletmeleri Örneği
}

\author{
DOI: 10.26466/opus.785657
}

\author{
$\underline{\text { Ahu Yazıc1 Ayyıldiz* - Muhammed Baykal** }}$ \\ *Dr.Öğr.Üyesi, Adnan Menderes Üniversitesi, Turizm Fakültesi \\ E-Posta: ayazici@adu.edu.tr \\ ORCID: $0000-0002-1301-2428$ \\ ** Doktora Öğrencisi, Adnan Menderes Üniversitesi, Sosyal Bilimler Enstitüsü \\ E-Posta: muhbarbay@gmail.com \\ ORCID: $\underline{0000-0002-7763-1949}$
}

Öz

Otel işletmelerinde konaklayan otel misafirlerinin şikâyete neden olacak deneyimlerinin çevrimiçi ortamlarda paylaşılmış olması, otel işletmelerinin mevcut ve potansiyel müşterilerinin kaybedilmesine neden olacaktır. Bu yüzden bu şikâyet konularının belirlenmesi ve çözüm yolu aranması gerekmektedir. Bu çalışmanın amacıda; otel misafirlerinin çevrimiçi ortamlarda yapmış olduğu şikâyetlerin kategorize edilmesi ve otel misafirlerinin milliyetine ve seyahat türüne göre en çok yoğunlaştı̆̆g şikâyet konularının belirlenmesidir. Araştırmada Kuşadası ilçesinde faaliyette bulunan beş yıldızl 15 otel işletmesi hakkında Tripadvisor web sitesinde yer alan 424 şikâyet yorumları içerik analizi ile incelenmiştir. Yapılan içerik analiz sonuçları formlara işlenmiş ve istatistik paket programına aktarılarak, frekans analizi yapılmıştır. Araştırma sonucunda; otel misafirlerinin otel işletmeleri hakkında yapmış oldukları e-şikâyetler, 11 kategoride kategorize edilmiştir. Şikâyetlerin en çok yoğunlaştığı kategoriler sırasıyla genel, yiyecek ve içecek, temizlik ve personel kategorileridir. En çok şikâyet alan konularm ise sırasıyla personelin tutumu, yemek lezzeti ve çeşitliliği, oda temizliği olduğu belirlenmiştir. Otel misafirlerinin milliyetine ve seyahat türüne göre en çok yoğunlaştığı şikâyet kategorileri ise genel, yiyecek ve içecek, temizlik ve personel kategorileridir. Bu noktada otel misafirlerinin milliyetinin veya seyahat türünün sonuçlara etki etmediği görülmüştür.

Anahtar Kelimeler: Kuşadası, e-şikâyet, konaklama işletmeleri 


\title{
Examination of E-Complaints Regarding Hotels with Content Analysis: The Example of 5 Star Hotels in Kuşadası
}

\begin{abstract}
The sharing of the experiences of guests staying in hotels that will cause complaints will cause the loss of existing and potential guests of hotels. So, it is necessary to determine these complaint issues and seek a solution. The aim of this study is the categorization of the complaints made by the hotel guests in online environments and the determination of the most concentrated complaint subjects according to the nationality of the hotel guests and the type of travel. In the research, 424 complaint comments on the Tripadvisor website about 15 five-star hotels in Kuşadast were analyzed through content analysis. The results of the content analysis made were entered into the forms and transferred to the statistical package program, and frequency analysis was performed. As a result of the research; e-complaints made by guests about hotels are categorized in 11 categories. The most concentrated categories of complaints are general, food and beverage, cleaning and personnel, respectively. It was determined that the subjects that received the most complaints were the attitude of the personnel, the taste and variety of the food, and the cleaning of the room, respectively. The complaint categories in which hotel guests are most concentrated according to their nationality and travel type are general, food and beverage, cleaning and personnel categories. At this point, it was observed that the nationality of the hotel guests or the type of travel did not affect the results.
\end{abstract}

Keywords: Kuşadası, e-complaint, hotels, 


\section{Giriş}

Teknolojinin gelişmesi ile birlikte insan yaşamına kolaylıklar sağlayacak birçok gelişme yaşanmıştır. Bu gelişmelerden biri de uçak gibi yeni seyahat etme araçlarının icat edilmesidir. Bu icatlar ile birlikte insanlar uzak yerlere seyahat etmeye başlamış ve ülkeler arasında sınırlar kalkmaya başlamıştır. Buna bağlı olarak da insanların tercihlerinde farklılıklar meydana gelmeye başlamıştır. Tüketiciler artık bir ürün veya hizmeti satın almadan önce ürün hakkında bilgi edinmek için çevrimiçi ortamlarda araştırma yapmaktadırlar. Satın aldıktan sonra da bu ortamlarda ürün hakkında yorum yaparak değerlendirmede bulunmaktadır. Daha önce tüketiciler ürün hakkında düşündüklerini akraba, arkadaş, eş ve yakın çevresi ile paylaşırken, günümüzde bu durum teknolojinin gelişmesinin etkisiyle çevrimiçi ortamlara taşınmıştır. Tüketiciler satın aldıkları ürün veya hizmeti deneyimleyerek iyi yönlerini ve zayıf yönlerini diğer kişilerin de görülebileceği bir ortamda paylaşabilmektedir. Bu paylaşımlar, geniş bir kitleye ulaşmakta birçok kişi tarafından dikkate alınmaktadır.

Tüketicilerin internete ve sosyal ağlara erişimi, daha kolay hale geldiğinden e-şikâyet ve yönetimi, hem kişiler hem de otel işletmeleri bakımından önemlidir (Ak ve Kızılırmak, 2019, s. 822). Bir otel misafirinin konaklamış olduğu bir otelde deneyimlediği olumlu ve olumsuz her şey Tripadvisor, Şikâyetvar.com, Holidaycheck ve Booking gibi web sitelerinde yer almaktadır. Yapılan bu yorumlar otel işletmesinde konaklamak isteyen bir kişinin satın alma kararını olumlu veya olumsuz olarak etkilemektedir. Otel misafirlerinin otel işletmelerine ilişkin yapmış olduğu olumlu yorumların veya şikâyetlerin hangi konularda sıklık yaşandığının tespiti, otel işletmelerinin yönlendirilmesinde yardımcı olacaktır (Gürbüz ve Ormankıran, 2020, s. 18). Özellikle otel misafirleri tarafından yapılan olumsuz yorumlar, otel işletmelerinin satışlarını olumsuz yönde etkileyeceği için bu yorumların dikkate alınması gerekmektedir. Bu nedenle otel misafirlerinin bir otel işletmesi hakkında yapmış olduğu şikâyet konuları belirlenmeli ve bu şikâyet konularına yönelik yeni stratejiler geliştirilmelidir. Bu sayede otel işletmeleri kötü imaja neden olacak bir durumu iyi bir imaja çevirebilecek fırsatı yakalayabilecektir. 
Bu çalışmanın amacı da; otel misafirlerinin çevrimiçi ortamlarda yapmış olduğu şikâyetlerin kategorize edilmesi, otel misafirlerinin milliyetine ve seyahat türüne göre en çok yoğunlaştığı şikâyet konularının belirlenmesidir.

\section{Kavramsal Çerçeve}

\section{E-şikâyet Kavramı}

Arapça kökenli bir kelime olan şikâyet kelimesi, yakınma anlamına gelmektedir. Turizm işletmeleri çerçevesinde değerlendirdiğimizde ise şikâyet kavramı, bir konu hakkında müşterilerin hoşnutsuzluğunu dışa vurması, geribildirimde bulunması ve üretim, satış, pazarlama, dağıtım sürecine dahil olması durumudur. Turizm işletmelerinin hizmet kalitesini artırması için önemli mesajlar içermektedir. Şikâyetler işletmelerin sunmuş olduğu ürün hakkında bu ürünü kullanan kullananlar tarafından verilen bir başarı karnesidir. İşletmeler, yüksek maliyetli araştırma ve geliştirme faaliyetleri ile ulaşılmak istenen bilgilere, ürün veya hizmet hakkında yapılan bir şikâyet ile daha kolay erişim sağlayabilmektedir (Doğan, Sert ve Tutan, 2016, s. 177).

Hizmet soyut bir kavram olduğu için özellikle hizmete dayalı olan turizm işletmelerinde müşteriler satın aldıkları ürün veya hizmeti deneme şansları yoktur. Bu nedenle müşterilerin kişisel deneyimlerine göre belirli bir ürün veya hizmet hakkındaki memnuniyetleri ya da memnuniyetsizlikleri satın alınan üründen faydalanıldığı sırada veya faydalanıldıktan sonra meydana gelmektedir (Alrawadieh ve Demirkol, 2015, s. 133).

Müşteriler belirli bir ürün veya hizmet hakkında şikâyet etme eğiliminde bulunurken farklı yöntemler ile bunu gerçekleştirebilmektedir. Bazı müşteriler ise şikâyet etme eğiliminde bulunmayarak satın almış olduğu ürünü veya hizmeti değiştirmek ile yetinmektedir. Müşteriler, ürün veya hizmet hakkında işletme ile direk olarak iletişim kurarak şikâyetlerini dile getirirken, bazı durumlarda da tüketici dernekleri, medya, seyahat acentesi ve tur operatörü gibi aracı işletmeler, yakın çevreleri veya tripadvisor, holidaycheck ve şikayetimvar gibi çevrimiçi ortamlarda şikâyelerini diğer tüketiciler ile paylaşmaktadırlar (Çetin Gürkan ve Dönmez Polat, 2014, s. 47).

E-şikayetler genellikle, belgeler, fotoğraflar ve videolar gibi kantlardan oluşan destekleyici içerikler aracilığıyla bir şirket veya markaya doğrudan 
hitap eden çevrimiçi şikayetlerdir. İçerik siteleri, müşterilerin kendi isteğiyle deneyimlerini başkalarıyla paylaşmalarına yardımcı olmaktadır. Müşterilerin deneyimlerini, yorumlarını ve şikayetlerini paylaştıkları çok popüler sanal platformlar haline gelen bu siteler bünyesinde (forumlar, şikâyet siteleri, inceleme siteleri vb.) faydalı içerikler barındırmaktadır (Özer Sarı ve Aşman Alikıliç, 2016, s. 79).

Farklı sosyal medya araçları aracilığıyla çevrimiçi ortamlarda yapılan tüketici yorumları, müşterinin işletmeden memnun kaldığını veya kalmadığını gösteren unsurların anlaşılması noktasında büyük bir öneme sahiptir. Müşteriler bu çevrimiçi ortamlarda işletme ile ilgili deneyimlerine bağlı olarak memnun kalma düzeylerini belirtebilmekte, işletmeden beklentilerini bildirmekte, puanlama yaparak yıldız verebilmekte ve yorum yapabilmektedirler. Diğer kişiler ise yapılan bu yorumları okuyarak yorumlara katılma derecelerini belirtebilmektedir. Çevrimiçi ortamda yapılan bu müşteri yorumları, otel işletmelerinin sunmuş olduğu hizmete ilişkin performanslarını müşterinin bakış açısıyla değerlendirmesine olanak tanımaktadır ve memnun kalmama unsurlarının belirlenmesi ve beklentilerin anlaşılması noktasında büyük önem taşımaktadır (Ercan, 2019, s. 556).

Literatürde yapılan çalışmalara bakıldığında; araştırmacıların birçoğu otel misafirlerinin otel işletmeleri hakkında yapmış oldukları e-şikâyetleri içerik analizi ile inceleyerek sınıflandırmaya çalışmışlardır. Ayrıca bazı araştırmacılar otel misafirlerinin demografik özellikleri, seyahat türü, konaklamış oldukları otelin sınıfı ile yapılan e-şikayetler arasında anlamlı bir ilişki olup olmadığını tespit etmişlerdir.

Lee ve Hu (2004), eComplaints.com adlı özel bir şikâyet forumuna kaydedilen otel misafirlerinin e-şikayetlerini analiz ederek, konu hakkında bazı bilgiler elde etmişlerdir. Otel misafirlerinin hizmet kalitesinin düşmesinden ve kaba çalışanlardan dolayı çoğunlukla mutsuz olduğu sonucuna varılmıştir.

$\mathrm{Au}$, Buhalis ve Law (2009), e-şikayetlerin içerik analizi ile kategorize edilmesi ve bu şikâyet kategorileri ile yaş ve otel sınıfı arasında anlamlı bir ilişki olup olmadığının belirlenmesi için bir çalıima yapmışlardır. 9 şikâyet kategorisi içerisinde en fazla şikâyet alan hizmet kategorisidir. E-şikâyet kategorileri ile otel sınıfı arasında anlamlı bir ilişki olmadığı, yaş ile şikâyet kategorileri arasında ise anlamlı bir ilişki olduğu bulunmuştur. Zheng, Young ve Kıncaid (2009) ise çevrimiçi yorumları kategorize ederek analiz et- 
mek ve otel misafirlerinin çevrimiçi şikâyet davranışlarını ortaya çıarmak ve çevrimiçi olarak yorum yapmasının nedenlerini belirlemek için bir çalışma yapmışlardır. Hizmete ilişkin şikâyetlerin odaya ilişkin şikâyetlerden daha fazla olduğu ve hizmet kategorisi içerisinde yer alan beklenen hizmetin alınmaması en fazla şikâyet alan konu olmuştur.

Levy, Duan ve Boo (2013), e-şikâyetlerin incelenmesi ve otelin itibarına zarar verebilecek şikâyetlere cevap verebilmek için stratejiler geliştirmek isteyerek bir çalışma yapmışlardır. En yaygın şikayetlerin ön büro personeli, banyo sorunları, oda temizliği ve misafir odası gürültü sorunları ile ilgili olduğu bulunmuştur. Özer Sarı, Alikılıç ve Onat (2013) ise e-şikayetlerin içeriğini analiz etmek ve işletmeler tarafından nasıl çözümlendiğini belirlemek için bir çalışma yapmışlardır. En yaygın şikâyet konularının yiyecek içecek hizmeti, odalar, ortak alanlar ve personelin nezaketi olduğu sonucuna varılmıştır. Barreda ve Bilgihan (2013) da otel misafirlerini çevrimiçi ortamlarda otel deneyimlerini değerlendirmeye motive eden ve en sık bahsedilen alanları kategorize ederek ana temaları belirlemek için bir çalışma yapmışlardır. Otel misafirleri yaygın olarak en çok temizlik konusunda şikâyetlerini dile getirmiştir. Ayrıca otel çalışanlarının eğitimli olması, otel misafirlerinin memnuniyeti artıran konulardan biri olduğu sonucuna varilmıştır.

Çetin Gürkan ve Dönmez Polat (2014) yapmış oldukları çalışmada otel misafirlerinin yapmış olduğu çevrimiçi şikâyetlerin içerik analizi ile kategorize edilmesi ve en yaygın şikâyet konularının belirlenmesini amaçlamışlardır. Beş ayrı kategori içerisinden yemek ve içecek yetersizliği ve kalitesizliği, yetersiz temizlik, odalardaki yetersiz malzeme ve arızaların en yaygın şikâyet konuları olduğu bulunmuştur. Au, Buhalis ve Law (2014) ise otellerle ilgili çevrimiçi şikayetlerin analiz edilerek kültür ile e-şikâyet niyetini etkileyen diğer faktörler arasındaki ilişkiyi incelemek için bir çalışma yapmışlardır. Şikâyet kategorilerinden hizmet kalitesinin hem yerli otel misafirleri hem de yabancı otel misafirleri için en çok şikâyet edilen kategorilerden biri olduğu bulunmuştur. Ayrıca otel misafirinin yaşının, otel fiyatının ve seyahat ortağının yapılan çevrimiçi şikayetleri önemli ölçüde etkilediği görülmüştür.

Memarzadeh ve Chang (2015) yapmış oldukları çalışmada daha iyi otel hizmetleri sunmak için otel misafirleri tarafından yapılan çevrimiçi incelemelerin önemine değinmek için e-şikâyetlerin içerik analizi ile kategorize 
edilmesi ve en yaygın şikâyet konularının belirlenmesini amaçlamışlardır. Çalışmada otel özelliklerinin kalitesizliği en yaygın ana kategori iken, personelin tutumu, düşük standart hizmet ve oda özelliklerinin kalitesizliği, bakımsızlığı ve arızalı olması ise en yaygın şikâyet alan konulardır. Alrawadieh ve Demirkol (2015) iseotel misafirlerinin demografik özelliklerini ele alınarak ve şikâyet edilen konuları inceleyerek çözüm yolları aramışlardır. Çalışmada hizmet kalitesinin düşük olması en çok şikâyet edilen konulardan biri olduğu ve bunu tesislerin kalitesi ve temizliği, personelin tutumu ve performansı izlediği sonucuna varılmıştır. Yiyecek ve içecek departmanı ise en çok şikâyet edilen departman olmuştur.

Behremen, Seçilmiş ve Akın (2017), helal konseptte çalışan konaklama işletmelerinde konaklayan otel misafirlerinin e-şikayetlerinin belirlenmesi için bir çalışma yapmışlardır. Yapılan çalışmada; en yaygın şikâyet konularının olanaklar, personel ve kablosuz internet olduğu belirlenmiştir. Dinçer ve Alrawadieh (2017) ise otel misafirlerinin şikâyetlerinin içerik analizi ile inceleyerek şikâyetlerin doğasını belirlemeye çalışmışlardır. Çalışmada en yaygın şikâyet kategorilerinin hizmet kalitesi, otel tesislerinin verimliliği, temizlik ve hijyen olduğu bulunmuştur. Doğan'ın (2017) yapmış olduğu çalışmada da çevrimiçi ortamda yapılan yorumlar analiz edilerek müşterimemnuniyetine ve memnuniyetsizliğine ilişkin unsurlar belirlenmiş ve otel işletmelerine çkarımlarda bulunulmuştur. Kötü hizmet kalitesi, yemeklerin lezzetsiz oluşu ve personelin işlerini iyi yapmaması en çok şikâyet edilen konular olarak belirlenmiştir. En çok şikâyetin yer aldığ 1 kategori ise yiyeceklerdir. Şahin, Kazoğlu ve Sönmez (2017) ise otel işletmelerine yönelik yapılan eşikâyetleri kategorilere ayırmak ve otel işletmelerinin şikâyetlerin ne kadarını yanıtladığını belirlemek için bir çalışma yapmışlardır. Altı farklı kategori içerisinden ürün kaynaklı sorunların en çok şikâyet alan kategori olduğu sonucuna varılmıştır.

Alrawadieh ve Law (2019), çevrimiçi incelemelerden yararlanarak otel işletmelerinde misafir memnuniyetini belirleyen temel faktörlerin belirlenmesi için bir çalışma yapmışlardır. Personelin hizmet kalitesi, odaların kalitesi ve büyüklüğünün misafir memnuniyetini belirleyen temel faktörler olduğu belirlenmiştir. Genç ve Batman (2018) ise tarihi otel işletmelerine yönelik eşikâyet konularının içerik analizi ile belirlenmesi ve otel işletmelerine öneriler sunulmasını amaçlamışlardır. Çalışma sonucunda; otel misafirlerinin en 
çok şikâyetçi olduğu konuların banyo ve tuvaletin küçük olması ve kahvaltının beklentiyi karşılayamaması olduğu belirlenmiştir.

Ak ve Kızılırmak (2019), otel işletmelerini e-şikâyetler ve e-şikâyet yönetimi bağlamında değerlendirmişlerdir. Yapılan çalışmada; otel misafirlerinin en çok odalara ve personele ilişkin konularda şikâyette bulunduğu ortaya çıkmıştır. Doğan, Karasakal ve Demirel (2019) ise otel işletmelerine yönelik yapılan e-şikâyetleri inceleyerek, otel işletmelerinin hizmet hatalarına neden olan unsurların ortaya çıkarılmasını ve bu unsurlar ile arasında bir ilişki olup olmadığının belirlenmesini amaçlamışlardır. Çalışma sonucunda; personel, banyo ve otel ekipmanı ve gürültü en çok şikâyetin yer aldığı kategoriler olarak belirlenmiştir. Personele ilişkin şikayetlerin çözüme kavuşturulması durumunda diğer kategorilerde yer alan şikâyetlerin de çözüme kavuşacağı vurgulanmıştır. Ercan'ın (2019) çalışmasında da, otel işletmeleri hakkında yapılan çevrimiçi yorumlarda müşteri memnuniyeti ve memnuniyetsizliğine neden olan unsurların belirlenmesi amaçlanmıştır. En çok şikâyetin yer aldığı ana unsurların yiyecekler, personel, hizmet ve ekipman eksiklikleri olduğu sonucuna varılmıştır. Ünal (2019) iseçevrimiçi şikâyet sitesi aracıllğıyla otel misafirlerinin e-şikâyetlerinin inceleyerek sinıflandırmayı ve şikâyetlerin hangi kategorilerde yoğunlaştığını belirlemeye çalışmıştır. Çalışma sonucunda; en çok şikâyetin yer aldığı kategorilerin hijyen ve temizlik olduğu görülmüş̧ür.

Gürbüz ve Ormankıran (2020), çevrimiçi ortamda yapılan otel işletmeleri hakkında otel misafirlerinin olumlu ve olumsuz yorumların inceleyerek kategorize etmişlerdir. Yapılan olumsuz yorumların en çok yoğunlaştığ şikâyet kategorilerinin hijyen, otel odaları, animasyon ve otel olanakları olduğu sonucuna varılmıştır. Zengin ve Haliloğlu (2020) ise otel işletmelerine yönelik e-şikâyetleri inceleyerek ve şikâyetleri kategorilere ayırarak, en çok şikâyet edilen konuların ortaya çıkarılmasını, otel işletmeleri için çözümler üretilmesini ve otel işletmelerinin bu şikâyetlerin ne kadarına yanıt verdiğinin belirlenmesi sağlamışlardır. Otel misafirlerinin en çok yoğunlaştığı şikâyet konularının fiyat uygulamaları ve personelin tutumu iken, en çok şikâyetin yer aldığı kategorilerin ise otel özellikleri, imkânları ve yönetim politikası olduğu belirlenmiştir. 


\section{Yöntem}

Araştırmada nitel ve nicel araştırma yöntemlerinden faydalanılmıştır. Çevrimiçi ortamda yer alan otel misafirlerinin şikâyetlerini kategorize etmek için nitel araştırma yöntemlerinden biri olan içerik analizi kullanılmıştır. İçerik analizi yoluyla e-şikâyetler kategorize edilmiş ve elde edilen bilgiler formlara işlenmiştir. Formlara işlenen bilgiler kodlanarak sayısal verilere dönüştürülmüştür. Dönüştürülen verilerin sayısal verilere dayalı olması nedeniyle de nicel araştırma yöntemlerinden faydalanılmıştır.

\section{Araştırmanın Önemi ve Amacı}

Hizmetin soyut bir kavram olması ve tüketicilerin satın almış olduğu hizmeti önceden deneme firsatının olmaması, tüketicilerin memnuniyet düzeyine etki etkilemektedir. Hizmete dayalı olan otel işletmelerinde de otel misafirleri satın almış olduğu hizmeti deneyimledikten sonra hizmet hakkında olumlu ve olumsuz düşüncelerini çevrimiçi web sitelerinde paylaşmaktadır. Özellikle bu sitelerde yer alan e-şikâyet olarak da adlandırılan olumsuz yorumlar, diğer kişiler tarafından okunmakta ve bu kişilerin satın alma kararını etkilemektedir. Aynı zamanda e-şikâyetler, bir otel işletmesi hakkında bir olumsuz imajın oluşmasına neden olmaktadır. Otel işletmeleri sahip olunan olumsuz imajı olumlu bir imaja dönüştürmesi zordur. Bu nedenle otel işletmeleri tarafından otel misafirlerinin en çok şikâyet ettiği konuların belirlenmesi ve kategorize etmesi gerekmektedir. Bu noktada araştırmadan elde edilen sonuçlar, otel işletmelerinin hangi konularda en çok şikâyet sıklığına sahip olduğunun tespiti ve bu sorunların çözüme kavuşturularak müşteri memnuniyetinin sağlanması açısından otel işletmelerine fayda sağlayacaktır. Ayrıca konu hakkında daha önce Aydın ilinin Kuşadası ilçesinde bir araştırma yapılmamış olması ve turizm sektöründe hizmetin en yoğun yaşandığı otel işletmeleri üzerine yapılmış olması, araştırmanın önemini ortaya koymaktadır.

Bu çalışmanın amacl; otel misafirlerinin çevrimiçi ortamlarda yapmış olduğu e-şikâyetlerin kategorize edilmesi, otel misafirlerinin milliyetine ve seyahat türüne göre en çok yoğunlaştığı şikâyet konularının belirlenmesidir. 


\section{Örneklem}

Araştırma Aydın'ın Kuşadası ilçesinde faaliyet gösteren 5 yıldızlı otel işletmeleri ile sinırlıdır. Aydın İl Kültür ve Turizm Müdürlügü̈ (2020) web sitesinde yer alan bilgilere göre Kuşadası'nda faaliyet gösteren 5 yıldızlı toplam 15 otel işletmesi bulunmaktadır. 29 Temmuz-12 Ağustos 2020 tarihleri arasinda 15 otel işletmesi hakkında Tripadvisor web sitesinde 2019 ve 2020 yıllarına ait Türkçe ve İngilizce dillerinde kötü ve berbat olarak yer alan toplam 424 yorum araştırma kapsamında değerlendirilmiştir.

\section{Veri Toplama Araçları ve Analizi}

Araştırma kapsamında yer alan toplam 424 e-şikâyet içerik analizi yoluyla kodlanarak kategorize edilmiştir. İçerik analizi, daha çok yazılı ve görsel verilerin çözümlenmesinde kullanılan yöntemlerden biridir. Tümdengelimci bir yol izlenen bu yöntemde araştırmacı ilk olarak araştırma konusuna ilişkin kategoriler oluşturmaktadır (Özdemir, 2010, s. 335). İçerik analizi ile elde edilen veriler sayısal verilere dönüştürülmüş ve SPSS 25 istatistik paket programına işlenmiştir. Şikâyetlerin sıklığın belirlemek için frekans analizinden faydalanılmıştır.

\section{Bulgular}

Araştırmanın bu bölümünde otel misafirlerinin seyahat türüne, milliyetine ve e-şikâyet kategorilerine ilişkin bulgular yer almaktadır.

\section{Otel Misafirlerinin Seyahat Türüne ve Milliyetine İlişkin Bulgular}

Bu bölümde otel misafirlerinin seyahat türüne ve milliyetine ilişkin bulgular yer almaktadır.

Tablo 1. Şikâyet eden kişilerin seyahat türü ve milliyetine ilişkin bilgiler

\begin{tabular}{lll}
\hline Seyahat Türü & $\mathbf{N}$ & $\%$ \\
\hline Aile & 243 & 57,3 \\
\hline Çift & 79 & 18,6 \\
\hline İş & 19 & 4,5 \\
\hline Arkadaş & 33 & 7,8 \\
\hline Yalnız & 8 & 1,9 \\
\hline Belirtilmemiş & 42 & 9,9 \\
\hline Milliyet & $\mathbf{N}$ & $\%$ \\
\hline Yerli & 252 & 59,4 \\
\hline Yabancı & 172 & 40,6 \\
\hline
\end{tabular}


Tablo 1'de şikâyet eden otel misafirlerinin milliyetine ve seyahat türüne ilişkin bilgiler yer almaktadır. Otel işletmelerini şikâyet eden otel misafirleri daha çok ailesi $(\% 57,3)$ ile birlikte konaklamışlardır. Otel işletmelerinde yalnız $(\% 1,9)$ olarak konaklayanların sayısı ise diğer seyahat türlerine göre daha azdır. Otel işletmelerini şikâyet eden yerli otel misafirlerinin sayısı $(\% 59,4)$, yabancı otel misafirlerine $(\% 40,6)$ göre daha fazladır.

\section{Otel İşletmelerine İlişkin E-şikâyet Kategorileri}

Bu bölümde otel işletmelerine yönelik e-şikâyet kategorilerine ilişkin bulgular yer almaktadır.

Tablo 2. Otel işletmelerine yönelik e-şikâyet kategorileri

\begin{tabular}{lll}
\hline Kategoriler & $\mathbf{N}$ & $\mathbf{\%}$ \\
\hline Genel & 456 & 21,8 \\
\hline Oda & 194 & 9,3 \\
\hline Yönetim & 109 & 5,3 \\
\hline Personel & 277 & 13,3 \\
\hline Temizlik & 292 & 13,9 \\
\hline Yiyecek ve İçecek & 416 & 19,9 \\
\hline Teknik Sorunlar & 125 & 5,9 \\
\hline Sağlık & 73 & 3,6 \\
\hline Eğlence & 64 & 3,0 \\
\hline İnternet & 32 & 1,5 \\
\hline Ulaşım & 53 & 2,5 \\
\hline TOPLAM & 2091 & 100 \\
\hline
\end{tabular}

Tablo 2'de otel işletmelerine yönelik e-şikâyet kategorileri yer almaktadır. Otel misafirlerinin şikâyetlerinin en çok genel (\%21,8) kategoride yoğunlaştı̆̆ı görülmektedir. Yiyecek ve içecek kategorisi de en çok şikâyetin yer aldığı bir diğer kategoridir. En az şikâyetin yer aldığ kategori ise internettir $(\% 1,5)$.

Milliyete göre e-şikâyet sıklkkları: Bu bölümde ise e-şikâyet sıklıklarının yerli ve yabancı otel misafirlerine dağılımına ilişkin bulgular yer almaktadır. 
Tablo 3. Milliyete göre e-şikâyet kategorileri

\begin{tabular}{lllll}
\hline Kategoriler & Yerli & $\mathbf{\%}$ & Yabancı & $\mathbf{\%}$ \\
\hline Genel & 281 & 23,3 & 175 & 19,8 \\
\hline Oda & 100 & 8,3 & 94 & 10,6 \\
\hline Yönetim & 63 & 5,2 & 46 & 5,2 \\
\hline Personel & 153 & 12,7 & 124 & 14,0 \\
\hline Temizlik & 171 & 14,3 & 121 & 13,7 \\
\hline Yiyecek ve İçecek & 245 & 20,3 & 171 & 19,3 \\
\hline Teknik Sorunlar & 71 & 5,9 & 54 & 6,1 \\
\hline Sağlık & 46 & 3,8 & 27 & 3,0 \\
\hline Eğlence & 38 & 3,1 & 26 & 2,9 \\
\hline İnternet & 6 & 0,5 & 26 & 2,9 \\
\hline Ulaşım & 32 & 2,6 & 21 & 2,4 \\
\hline TOPLAM & 1206 & 100 & 885 & 100 \\
\hline
\end{tabular}

Tablo 3'te yerli ve yabancı otel misafirlerinin e-şikâyet sıklıklarına ilişkin bilgiler yer almaktadır. Hem yerli otel misafirlerinin (\%23,3) hem de yabanc1 otel misafirlerinin $(\% 19,8)$ en çok genel kategori içerisinde yer alan konulardan şikâyetçi olduğu görülmektedir. Ancak yerli otel misafirlerin en az şikâyetçi olduğu kategori internet iken, yabancı otel misafirlerinin ise ulaşımdır.

Seyahat türüne göre e-şikâyet sıklıklarn: Bu bölümde ise e-şikâyet sıklıklarının seyahat türüne göre dağılımına ilişkin bulgular yer almaktadır.

Tablo 4. Seyahat türüne göre e-şikâyet kategorileri

\begin{tabular}{lllllll}
\hline Kategoriler & Aile & Çift & İş & Arkadaş & Yalnız & Belirtilmemiş \\
\hline Genel & 268 & 90 & 14 & 31 & 12 & 41 \\
\hline Oda & 102 & 29 & 13 & 16 & 12 & 22 \\
\hline Yönetim & 66 & 18 & 5 & 7 & 2 & 11 \\
\hline Personel & 142 & 63 & 8 & 26 & 8 & 30 \\
\hline Temizlik & 173 & 54 & 5 & 19 & 11 & 30 \\
\hline Yiyecek ve İçecek & 223 & 78 & 18 & 35 & 10 & 52 \\
\hline Teknik Sorunlar & 65 & 30 & 4 & 10 & 2 & 14 \\
\hline Sağlık & 43 & 13 & 3 & 7 & 1 & 6 \\
\hline Eğlence & 35 & 14 & 2 & 6 & - & 7 \\
\hline İnternet & 18 & 6 & 1 & 1 & 2 & 4 \\
\hline Ulaşım & 34 & 9 & 2 & 3 & 1 & 4 \\
\hline TOPLAM & 1169 & 404 & 75 & 161 & 61 & 221 \\
\hline
\end{tabular}

Tablo 4'te otel misafirlerinin seyahat türüne göre e-şikâyet sıklıkları gösterilmektedir. Otel işletmelerinde ailesiyle birlikte ve çift olarak konaklayan otel misafirlerinin en çok genel kategori içerisinde yer alan konulardan 
şikâyetçi olduğu, en az ise internetten şikâyetçi olduğu görülmektedir. Otel işletmelerinde iş amaçlı ve arkadaşları ile birlikte konaklayan misafirler ise en çok yiyecek ve içecek kategorisi içerisinde yer alan konulardan, en az ise internet kategorisi içerisinde yer alan konulardan şikâyetçi olmuşlardır. Yalnız olarak konaklayan otel misafirleri ise en çok genel ve oda kategorisi içerisinde yer alan konulardan şikâyetçi olmuşlardır. Ancak yalnız olarak konaklayan otel misafirlerinin eğlence kategorisinde yer alan konuların hiçbirinden şikâyetçi olmadığı görülmektedir. Seyahat türünü belirtmeyen otel misafirleri ise en çok yiyecek ve içecek kategorisinde yer alan konulardan, en az ise internet ve ulaşım kategorilerinde yer alan konulardan şikâyetçi oldukları görülmektedir.

Otel işletmelerine yönelik e-şikayet alt kategorileri: Bu bölümde de otel işletmelerine yönelik e-şikayetlerin alt kategorilerine ilişkin bulgular yer almaktadır.

Tablo 5.Genel e-şikâyet alt kategorileri

\begin{tabular}{|c|c|c|c|}
\hline Kategori & Şikâyet Konusu & $\mathbf{N}$ & Örnek Yorum \\
\hline \multirow{15}{*}{$\begin{array}{l}\text { GENEL } \\
(456)\end{array}$} & Otel Mimarisi & 2 & \multirow{15}{*}{$\begin{array}{l}\text { “...ilk karşınıza çıkan havuzda yüzemez- } \\
\text { siniz sadece ayakta beklersiniz. Çok kala- } \\
\text { balık...” (O10) } \\
\text { “Otele yatırım yapılmış ancak hizmet } \\
\text { kalitesi çok kötü, paranı hakkını vermi- } \\
\text { yor.” (O8) }\end{array}$} \\
\hline & Hizmet Kalitesi & 80 & \\
\hline & Fiyat-Fayda Dengesi & 54 & \\
\hline & Güvenlik & 30 & \\
\hline & Gürültü & 34 & \\
\hline & Işıklandırma & 10 & \\
\hline & Otopark & 3 & \\
\hline & Müşteri Profili & 9 & \\
\hline & Yönlendirme & 2 & \\
\hline & Bilgilendirme & 10 & \\
\hline & Yoğunluk & 84 & \\
\hline & Ortak Kullanım Alanlarının Yetersizliği & 18 & \\
\hline & $\begin{array}{l}\text { Ortak Kullanım Alanlarındaki } \\
\text { Ekipman ve Malzeme Eksikliği }\end{array}$ & 50 & \\
\hline & Ortak Kullanım Alanı Ekipman Bakımı & 57 & \\
\hline & Yaniltıcı Tanitım & 13 & \\
\hline
\end{tabular}

Tablo 5 'te genel kategorisi içerisinde yer alan e-şikayetlerin alt kategorilerine ilişkin bilgiler ve örnek yorumlar yer almaktadır. Genel kategorisi içerisinde yer alan e-şikâyetlerin alt kategorilerinin sıklığına bakıldığında; otel misaflerinin daha çok otelin yoğunluğundan ve hizmet kalitesinden şikâyetçi oldukları görülmektedir. Otel misafirlerinin en az şikâyetçi olduk- 
ları alt kategorilerin ise otelin mimari yapısı, otoparkın yetersiz oluşu ve otel içerisinde yönlendirmelerin olmamasının olduğu görülmektedir.

Tablo 6. Oda e-şikâyet alt kategorileri

\begin{tabular}{|c|c|c|c|}
\hline Kategori & Şikâyet Konusu & $\mathbf{N}$ & Örnek Yorum \\
\hline \multirow{6}{*}{$\begin{array}{l}\text { ODA } \\
(194)\end{array}$} & Odanın Konumu & 16 & \multirow{6}{*}{$\begin{array}{l}\text { "...4 kişi olmamıza rağmen } 3 \text { havlu bırakılmış..." } \\
(\mathrm{O} 15)\end{array}$} \\
\hline & Odanın Dizaynı & 2 & \\
\hline & Konfor & 33 & \\
\hline & Oda Genişliği & 21 & \\
\hline & $\begin{array}{l}\text { Oda Ekipman ve } \\
\text { Malzeme Eksikliği }\end{array}$ & 71 & \\
\hline & Oda Ekipman Bakımı & 51 & \\
\hline
\end{tabular}

Tablo 6'da oda kategorisi içerisinde yer alan e-şikayetlerin alt kategorilerine ilişkin bilgiler ve örnek yorum yer almaktadır. Oda kategorisi içerisinde yer alan e-şikâyetlerin alt kategorilerinin sıklığına bakıldığında; otel misaflerinin daha çok oda ekipman ve malzeme eksikliği konusunda şikâyetçi oldukları görülmektedir. Otel misafirlerinin en az şikâyetçi oldukları alt kategorinin ise odanın dizaynı olduğu görülmektedir.

Tablo 7. Yönetim e-şikâyet alt kategorileri

\begin{tabular}{|c|c|c|c|}
\hline Kategori & Şikâyet Konusu & $\mathbf{N}$ & Örnek Yorum \\
\hline \multirow{5}{*}{$\begin{array}{l}\text { YÖNETIMM } \\
\text { (109) }\end{array}$} & Yönetimin Tutumu & 62 & \multirow{5}{*}{$\begin{array}{l}\text { "5 günlük tatilin } 3 \text { gününü kendi çabala- } \\
\text { rimizla telefonu arayarak geçirdik. Otel } \\
\text { yönetimi zahmet edip kamera göruntüle- } \\
\text { rini bile izlemedi." (O8) }\end{array}$} \\
\hline & Yönetimin Yetkinliği & 18 & \\
\hline & Yönetim Eksikliği & 7 & \\
\hline & $\begin{array}{ll}\text { Verilen Vaatlerin } & \text { Yerine } \\
\text { Getirilmemesi } & \end{array}$ & 13 & \\
\hline & Geri Ödeme & 9 & \\
\hline
\end{tabular}

Tablo 7'de yönetim kategorisi içerisinde yer alan e-şikayetlerin alt kategorilerine ilişkin bilgiler ve örnek yorum yer almaktadır. Yönetim kategorisi içerisinde yer alan e-şikâyetlerin alt kategorilerinin sıklığına bakıldığında; otel misaflerinin daha çok yönetimin tutumu konusunda şikâyetçi oldukları görülmektedir. Otel misafirlerinin en az şikâyetçi oldukları alt kategorilerin ise yönetim eksikliği ve geri ödemenin yapılmaması olduğu görülmektedir

Tablo 8. Personel e-şikâyet alt kategorileri

\begin{tabular}{|c|c|c|c|}
\hline Kategori & Şikâyet Konusu & $\mathbf{N}$ & Örnek Yorum \\
\hline \multirow{3}{*}{$\begin{array}{l}\text { PERSONEL } \\
\text { (277) }\end{array}$} & Personelin Tutumu & 187 & \multirow{3}{*}{$\begin{array}{l}\text { "...iki farklı olayda garson ve barmenin } \\
\text { çocuklara çok kaba davrandığını gördüm." } \\
\text { (O5) }\end{array}$} \\
\hline & Personelin Yetkinliği & 50 & \\
\hline & Personel Eksikliği & 40 & \\
\hline
\end{tabular}


Tablo 8'de personel kategorisi içerisinde yer alan e-şikayetlerin alt kategorilerine ilişkin bilgiler ve örnek yorum yer almaktadır. Personel kategorisi içerisinde yer alan e-şikâyetlerin alt kategorilerinin sıklığına bakıldığında; otel misafirlerinin daha çok personelin tutumu konusunda şikâyetçi oldukları görülmektedir. Otel misafirlerinin en az şikâyetçi oldukları alt kategorinin ise personel eksikliği olduğu görülmektedir.

Tablo 9. Temizlike-şikâyet alt kategorileri

\begin{tabular}{|c|c|c|c|}
\hline Kategori & Şikâyet Konusu & $\mathbf{N}$ & Örnek Yorum \\
\hline \multirow{5}{*}{$\begin{array}{l}\text { TEMİZLİK } \\
\text { (292) }\end{array}$} & Ortak Kullanım Alanlarının Temizliği & 76 & \multirow{5}{*}{$\begin{array}{l}\text { “Odalar büyük olma potansiyeli- } \\
\text { ne sahipti ama temizlik çok } \\
\text { zayfftı." (O13) }\end{array}$} \\
\hline & Oda Temizliği & 125 & \\
\hline & Otel Ekipmanlarının Temizliği & 27 & \\
\hline & Havuz Bakımı & 26 & \\
\hline & Deniz ve Plaj Bakımı & 38 & \\
\hline
\end{tabular}

Tablo9'da temizlik kategorisi içerisinde yer alan e-şikayetlerin alt kategorilerine ilişkin bilgiler ve örnek yorum yer almaktadır. Temizlik kategorisi içerisinde yer alan e-şikâyetlerin alt kategorilerinin sıklığına bakıldığında; otel misaflerinin daha çok oda temizliği konusunda şikâyetçi oldukları görülmektedir. Otel misafirlerinin en az şikâyetçi oldukları alt kategorilerinin ise havuz bakımı ve otel ekipmanlarının temizliği olduğu görülmektedir.

Tablo 10. Yiyecek ve içecek e-şikâyet alt kategorileri

\begin{tabular}{|c|c|c|c|}
\hline Kategori & Şikâyet Konusu & $\mathbf{N}$ & Örnek Yorum \\
\hline \multirow{7}{*}{$\begin{array}{l}\text { YİYECEK } \\
\text { İÇECEK } \\
(416)\end{array}$} & Yemek Lezzeti & 129 & \multirow{7}{*}{$\begin{array}{l}\text { "Yemeklere gelince çok az çeşit var ve soğuk } \\
\text { yemekler. Tatlılara gelince tatlımız var diye } \\
\text { konulmuş çeşit az ve eminim yemezsiniz." } \\
(\mathrm{O} 2)\end{array}$} \\
\hline & Yemek Çeşitliliği & 129 & \\
\hline & Yiyecek Kalitesi & 44 & \\
\hline & İçecek Tadı & 9 & \\
\hline & İçecek Çeşitliliği & 25 & \\
\hline & İçecek Kalitesi & 45 & \\
\hline & Yemek ve İçecek Sunumu & 35 & \\
\hline
\end{tabular}

Tablo 10 'da yiyecek ve içecek kategorisi içerisinde yer alan e-şikayetlerin alt kategorilerine ilişkin bilgiler ve örnek yorum yer almaktadır. Yiyecek ve içecek kategorisi içerisinde yer alan e-şikâyetlerin alt kategorilerinin sıklığına bakıldığında; otel misaflerinin daha çok yemek lezzeti ve çeşitliliği konusunda şikâyetçi oldukları görülmektedir. Otel misafirlerinin en az şikâyetçi oldukları alt kategorinin ise içeceklerin tadı olduğu görülmektedir. 
Tablo 11.Teknik sorunlar e-şikâyet alt kategorileri

\begin{tabular}{|c|c|c|c|c|}
\hline Kategori & Şikâyet Konusu & & $\mathbf{N}$ & Örnek Yorum \\
\hline \multirow{2}{*}{$\begin{array}{l}\text { Teknik } \\
\text { Sorunlar (125) }\end{array}$} & $\begin{array}{l}\text { Ortak Kullanım Alanı } \\
\text { Arıza }\end{array}$ & Ekipman & 33 & \multirow{2}{*}{$\begin{array}{l}\text { “...banyoyu su bastı. İkinci odada havluluk } \\
\text { elimizde kaldı, kapı kolu da öyle...” (O1) }\end{array}$} \\
\hline & Oda Ekipman Arıza & & 92 & \\
\hline
\end{tabular}

Tablo 11 'de teknik sorunlar kategorisi içerisinde yer alan e-şikayetlerin alt kategorilerine ilişkin bilgiler ve örnek yorum yer almaktadır. Teknik sorunlar kategorisi içerisinde yer alan e-şikâyetlerin alt kategorilerinin sıkl1ğına bakıldığında; otel misaflerinin daha çok oda ekipman arızaları konusunda şikâyetçi oldukları görülmektedir. Otel misafirlerinin en az şikâyetçi oldukları alt kategorinin ise ortak kullanım alanı ekipman arızaları olduğu görülmektedir.

Tablo 12. Sağlık e-şikâyet alt kategorileri

\begin{tabular}{llll}
\hline Kategori & Şikâyet Konusu & N & Örnek Yorum \\
\hline \multirow{4}{*}{$\begin{array}{l}\text { SAĞLIK } \\
\text { (73) }\end{array}$} & $\begin{array}{l}\text { Sağllk Hizmetlerinin Yetersiz- } \\
\text { liği }\end{array}$ & 5 & \\
\cline { 2 - 3 } & Sağllk Önlemleri & 20 & "Eşim ve ben gida zehirlenmesi nedeniyle 4 \\
\cline { 2 - 3 } & Glda Güvenliği & 32 & \\
\cline { 2 - 3 } & İaçlama & 16 & \\
\hline
\end{tabular}

Tablo 12'de sağlık kategorisi içerisinde yer alan e-şikayetlerin alt kategorilerine ilişkin bilgiler ve örnek yorum yer almaktadır. Sağlık kategorisi içerisinde yer alan e-şikâyetlerin alt kategorilerinin sıklığına bakıldığında; otel misaflerinin daha çok gıda güvenliği konusunda şikâyetçi oldukları görülmektedir. Otel misafirlerinin en az şikâyetçi oldukları alt kategorinin ise otel işletmelerindeki sağlık hizmetlerinin yetersizliği olduğu görülmektedir.

Tablo 13. Ĕ̆lence e-şikâyet alt kategorileri

\begin{tabular}{llll}
\hline Kategori & Şikâyet Konusu & $\mathbf{N}$ & Örnek Yorum \\
\hline \multirow{2}{*}{$\begin{array}{l}\text { EĞLENCE } \\
\text { (64) }\end{array}$} & Etkinlik Çeşitliliği & 59 & \multirow{2}{*}{ “Doluluk yoğun olmasına rağmen akşam } \\
\cline { 2 - 3 } & Lobi Müziği & 4 & hiç bir eğlence olmad.” (O3) \\
\cline { 2 - 3 } & Su Sporları & 1 & \\
\hline
\end{tabular}

Tablo $13^{\prime}$ te eğlence kategorisi içerisinde yer alan e-şikayetlerin alt kategorilerine ilişkin bilgiler ve örnek yorum yer almaktadır. Eğlence kategorisi içerisinde yer alan e-şikâyetlerin alt kategorilerinin sıklığına bakıldığında ise otel misaflerinin daha çok etkinliklerin çeşitliliği konusunda şikâyetçi oldukları görülmektedir. Otel misafirlerinin en az şikâyetçi oldukları alt kategorinin ise su sporları olduğu görülmektedir. 
Tablo 14. Internet e-şikâyet alt kategorileri

\begin{tabular}{llll}
\hline Kategori & Şikâyet Konusu & N & Örnek Yorum \\
\hline İNTERNET & İnternetin Kapsama Alanı & 27 & "Wi-fi sadece lobi katında resepsiyona yakın \\
\cline { 2 - 3 } (32) & İnternet Hızı & 5 & yerde çekiyordu." (O5) \\
\hline
\end{tabular}

Tablo 14'teinternet kategorisi içerisinde yer alan e-şikayetlerin alt kategorilerine ilişkin bilgiler ve örnek yorum yer almaktadır. İnternet kategorisi içerisinde yer alan e-şikâyetlerin alt kategorilerinin sıklığına bakıldığında; otel misaflerinin daha çok internet kapsama alanıkonusunda şikâyetçi oldukları görülmektedir. Otel misafirlerinin en az şikâyetçi oldukları alt kategorinin ise intenet hızıolduğu görülmektedir.

Tablo 15. Ulaşım e-şikâyet alt kategorileri

\begin{tabular}{|c|c|c|c|}
\hline Kategori & Şikâyet Konusu & $\mathbf{N}$ & Örnek Yorum \\
\hline \multirow{2}{*}{$\begin{array}{l}\text { ULAŞIM } \\
\text { (53) }\end{array}$} & Merkeze Yakınlık & 9 & \multirow{2}{*}{$\begin{array}{l}\text { "Gelelim odadan havuza yada plaja inme } \\
\text { mevzusuna. Asansörsüz inmek imkansız ve } \\
3 \text { asansör değiştirmek zorundasını.." (O10) }\end{array}$} \\
\hline & Tesis İçi Ulaşım & 44 & \\
\hline
\end{tabular}

Tablo 15'te ulaşım kategorisi içerisinde yer alan e-şikayetlerin alt kategorilerine ilişkin bilgiler ve örnek yorum yer almaktadır. Ulaşım kategorisi içerisinde yer alan e-şikâyetlerin alt kategorilerinin sıklığına bakıldığında; otel misaflerinin daha çok tesis içi ulaşım konusunda şikâyetçi oldukları görülmektedir. Otel misafirlerinin en az şikâyetçi oldukları alt kategorinin ise merkeze yakınlık olduğu görülmektedir.

\section{Tartışma ve Sonuç}

Otel misafirleri satın almış olduğu hizmeti daha önceden görme fırsatı olmadığı için hizmeti deneyimledikten sonra değerlendirebilmektedir. Günümüzde birçok kişinin hizmeti satın almadan önce okudukları e-şikâyetler, satın alma kararında önemli bir etkiye sahiptir. E-şikayetler, hizmete dayalı olan otel işletmelerine eksikliklerini görmesi açısından yardımcı olmaktadır. Bu nedenle otel işletmeleri açısıdan büyük önem taşımaktadır.

Araştırmada seyahat türüne ilişkin bulgulara bakıldığında, e-şikâyet bildiriminde bulunan otel misafirlerinin daha çok aileleri ile birlikte konakladıkları görülmektedir. Otel işletmelerinde yalnız olarak konaklayanların sayısı ise diğer seyahat türlerine göre daha azdır. E-şikâyet bildiriminde bulunan yerli otel misafirlerinin sayısı da yabancı otel misafirlerine göre daha fazladır. Ak ve Kızılırmak (2019) ile Alrawadieh ve Demirkol (2015) ise yapmış oldukları çalışmada yabancı otel misafirlerinin yerli misafirlere göre 
daha fazla olduğunu belirmişlerdir. Bu noktada araştırmanın sonuçları birbirinden farklılık göstermektedir. Bunun nedeni; araştırmanın yapıldığ bölgedeki otel misafirlerinin profilinin farklı olması gösterilebilir. Ayrıca aileleri ile birlikte konaklayan ve yerli otel misafirlerinin daha çok şikâyet bildirme eğiliminde oldukları da söylenebilir.

E-şikâyet bildiriminde bulunan otel misafirlerinin toplam 11 şikâyet kategorisi içerisinden daha çok genel şikâyet kategorisi içerisinde yer alan konulardan şikâyetçi olmuşlardır. Bununla birlikte yiyecek ve içecek kategorisi de en çok şikâyet bildirilen kategorilerdendir. Ancak otel misafirlerinin az bir kısmı internet şikâyet kategorisi içerisinde yer alan konulardan şikâyetçi olmuşlardır. Bu bağlamda, bölgede yer alan otel işletmelerinin yiyecek ve içecek konusunda eksikliklerinin olduğu görülmektedir. Bununla birlikte bölgedeki otel işletmelerinin birçoğunda internet alt yapısının iyi olduğu söylenebilir.

Seyahat türüne göre e-şikâyet sıklığına bakıldığında ise ailesiyle ve çift olarak konaklayan otel misafirler en çok genel şikâyet kategorisi içerisinde yer alan konulardan, en az ise internet şikâyet kategorisi içerisinde yer alan konulardan şikâyetçi olmuşlardır. Özellikle genel şikâyet kategorisi içerisinde yer alan yoğunluk konusunda otel misafirlerinin çok fazla şikâyet bildiriminde bulunduğu düşünüldüğünde, bunun nedeni olarak bölgedeki otel işletmelerinin taşıma kapasitelerinin üzerinde misafirleri ağırlaması olduğu söylenebilir. Otel işletmelerinde iş amaçlı ve arkadaşları ile birlikte konaklayan otel misafirleri ise en çok yiyecek ve içecek kategorisi içerisinde yer alan konulardan, en az ise internet kategorisi içerisinde yer alan konulardan şikâyetçi olmuşlardır. Yalnız olarak konaklayan otel misafirleri ise en çok genel ve oda kategorisi içerisinde yer alan konulardan şikâyetçi olmuşlardır. Ancak yalnız olarak konaklayan otel misafirlerinin eğlence kategorisinde yer alan konuların hiçbirinden şikâyetçi olmadığı görülmektedir.

Alt şikâyet kategorilerine ilişkin e-şikâyet bildirimlerinin sıklığına bakıldığında; otel misafirlerinin çoğunluğu otelin mimari yapısından, yönlendirmelerden ve otopark kapasitesinden memnun iken hizmet kalitesi, yoğunluk, fiyat-fayda dengesi ve ortak kullanım alanlarındaki ekipmanların bakımı ve eksiliğinden dolayı şikâyetçilerdir. Otel misafirleri daha sakin ve az kişinin olduğu ortamlarda tatil yapmak ve satın almış olduğu hizmetin vermiş olduğu ücrete değer olmasını istemektedirler. Otel misafirleri odanın görünümünden çok odadaki ekipmanların ve malzemelerin eksiksiz olma- 
sinı tercih etmektedirler. Ayrıca otel yönetiminin ve personelin tutumundan dolayı rahatsız oldukları görülmektedir. Temizlik konusunda ise otel misafirleri en çok oda temizliğinden memnun kalmamaktadır. Otel işletmelerinde yemeklerin lezzetsiz oluşu ve çeşitliliğin olmayışı, yiyecek ve içecek konusunda en çok şikâyet bildirilen konudur. Otel misafirleri en çok odadaki ekipmanlardan dolayı teknik sorun yaşamaktadırlar. Otel işletmelerinin birçoğunun gıda güvenliği konusunda önlemler almadığı görülmektedir. Otel misafirlerinin konakladıkları otel işletmelerinde yeteri kadar etkinliklerin olmayışı ise bir başka şikâyet konusudur. İnternet konusunda çok şikâyet bildiriminde bulunulmasa da otel misafirleri internetin kapsama alanı konusunda daha çok şikâyette bulunmuştur. Ayrıca otel misafirleri odalarının ortak kullanım alanlarına yakın olmasını istemektedirler. Daha önce yapılan çalışmaların (Lee ve Hu, 2004; Barreda ve Bilgihan, 2013; Levy vd., 2013; Özer Sarı vd., 2013; Çetin Gürkan ve Dönmez Polat, 2014; Alrawadieh ve Demirkol, 2015; Memarzadeh ve Chang, 2015; Doğan, 2017; Ercan, 2019; Zengin ve Haliloğlu, 2020) sonuçlarına bakıldığında; ortak şikâyet konularının hizmet kalitesi, yiyecek ve içecek, personelin tutumu ve oda temizliği olduğu görülmektedir. Bu doğrultuda araştırmanın sonucu ile benzerlik göstermektedir.

Yapılan şikâyet konuları ışığında; otel işletmelerinin taşıma kapasitelerinin üzerine çıkmaması gerekmektedir. Hizmet kalitesinden ödün vermemeli, oda temizliğine dikkat edilmelidir. Hem yönetim hem de personel davranışlarına dikkat etmeli ve personele bu konuda eğitim verilmelidir. Odadaki ekipmanlar ve malzemeler eksiksiz olmalı ve misafire oda verilmeden önce ekipman arızaları giderilmelidir. Otel işletmeleri yemek çeşitliliğini artırmalı ve aş̧̧ılara daha lezzetli yemekler yapılması noktasında uyarılarda bulunmalı ve gıda güvenliği konusunda önlemler almalıdır. Ayrıca etkinlikler artırılarak otel misafirinin tesis içinde eğlenmesine olanak tanınmalıdır. İnternetin kapsama alanı genişletilmeli, lobi dışında odalarda da bağlantı kurma imkânı sunulmalıdır. Tesis içinde ortak kullanım alanlarına ulaşımı kolaylaştıracak adımlar atılmalıdır.

Türkiye'nin ilk turizm merkezlerinden biri olan Kuşadası'nda yapılan bu çalışma, farklı bir turizm destinasyonunda da yapılabilir. Ayrıca otel işletmeleri dışında, yiyecek ve içecek işletmelerinde ve seyahat acentelerinde bir çalışma yapılarak bölgedeki işletmelerin eksikliklerini görmesi sağlanabilir. 


\title{
EXTENDED ABSTRACT
}

\section{Examination of E-Complaints Regarding Hotels with Content Analysis: The Example of 5 Star Hotels in Kuşadası}

\author{
Ahu Yazıcı Ayyıldız - Muhammed Baykal \\ Aydin Adnan Menderes University
}

Consumer comments which are made as online by different social media tools have importance about whether customers are satisfied with the establishment or not. Customers can express their satisfactory levels depending on their experiences in online environments, declare their expectations from the businesses, give star by scoring and comment. Other people read these commnets and epresstheir level of acceptaions about these comments. Customers comments in online environments provide the hotels to evaluate their service performances through the customers' point of wievs. It carries a big importance whether they are satisfied or not and understanding the expectations (Ercan, 2019, p. 556).

When looking at the studies in the literature (Lee and $\mathrm{Hu}, 2004$; Au et al., 2009; Zheng et al., 2009; Barreda and Bilgihan, 2013; Levy et al., 2013; Özer Sar1 et al., 2013; Au vd., 2014; Çetin Gürkan and Dönmez Polat, 2014; Alrawadieh and Demirkol, 2015; Memarzadeh and Chang, 2015; Behremen et al., 2017; Dinçer and Alrawadieh, 2017; Doğan, 2017; Şahin et al., 2017; Genç and Batman, 2018; Ak and Kızılırmak, 2019; Alrawadieh and Law, 2019; Doğan et al., 2019; Ercan, 2019; Ünal, 2019; Gürbüz and Ormankıran, 2020; Zengin and Haliloğlu, 2020), most of researchers have tried to classify the ecomplaints from the hotel guests about the hotels by examining with content analysis. However, some researchers determined whether there is a meaningful correlation between the hotel guests' demographic features, travel types and the class of hotel stayed and e-complaints.

The aim of this study is to categorize the e-complaints made in online environments and to determine the types of complaints according to the hotel guests' nationality and travel types.

In this study qualitative and quantitive research methods have been used. In order to categorize the the hotels guests' complaints in online envi- 
ronments, content analysis, one of qualitative research methods has been used. E-complaints have benn categorized by means of content analysis and the obtained information has been written on forms. The information written on forms has been transferred to digital data by coding them. Because the transferred data is based on numerical data, quantative research methods have been used.

The study is limited to five star hotels in Kuşadası district of Aydın. There are 15 hotels in Kuşadası according to the informatin given on Aydın Provincial Directorate of Culture and Tourism' (2020) web site. Between 29 July and 12 August 2020, a total of 424 reviews about 15 hotels in Turkish and English languages for 2019 and 2020 on the Tripadvisor site have been evaluated within the scope of the study.

A total of 424 complaints within the scope of the research have been coded and categorized thorugh the content analysis. Data obtained through the content analysis have been transfered into numerical data and processed into the statistics package program. In order to determine the frequncy of complaints, frequecy analysis has been used.

At the end of the result, it has been observed that hotel guests who have filled a complaint form complained more than the complaint categories in the general complaint category. Hovewer food and beverage have been the ones complained too much. In the meanwhile a small proportion of hotel guests have complained about the issues in the internet complaint category. As result, it has been observed that hotels in this region have some lacks about food and beverage. Hovewer it can be said that hotels in this region have a good internet infrastructure.

When looking by the type of travel, hotelguests who stay with their families or as couples have complained the issues the most general complaint category and at least the issues in the internet complaint category. Considering that there are too many complaints from the hotel guests especially regarding the density in the general complaint category, it can be said that the reason for this is that hotels in the region have a guest weight over their capacity. The hotel guests staying in ahotel for the purpose of work or with their families have complained the issues most the food and beverage and at least the issues in the internet category. The hotel guests staying alone have comlained the issues the most in the general and room category. But it has 
been observed that hotel guests staying alone haven't comlained the issues in the entertainment categories.

Consedering the frequency of complaint notifications related to sub categories of complaints, the majority of guests are satisfied with the manegement of the hotel, architectural structure and parking capacity. Hotel guests prefer staying at calmer and less crowded places. They prefer complete room equipments than the apperance of the room. Hovewer it has been observed that they are restless because of the behavior of the hotel manegement, staff, cleaning. The lack of flavor and variety of the hotel isthe most frequently reported issue regarding food and drink. The hotel guests have technical problems the most about the room equipments. It has been observed that hotels don't take precutions about food safety. Another complaint issue is the lack of activities in the hotels. Although the aren't many complaints about internet, they have complaint the internet coverage area. And hotel guests want their rooms to be near the common area.

In the light of complaints made, hotels shoudn't exceed their carrying capacity. Hotels shouldn't compromise on service quality and should be careful about room cleaning. Both management and staff should be educated about this issue. Materials and equipment should be complete and before giving it to the guests, malfunction and equipment must be eliminated. Hotels should increase the food varieties and cooks should be warned to cook more delicious food. Precautions about food safety should be taken. By increasing the activities hotel guests should be allowed to have fun on the site. Internet coverage area should be enhanced and the possibility to establish connections outside the lobby should also be provided. Steps should be taken to facilitate access to common areas.

\section{Kaynakça / References}

Ak, S. ve Kızılırmak, İ. (2019). Otel işletmelerinde e-şikâyetler ve e-şikâyet yönetimi üzerine bir araştırma. Türk Turizm Araştırmaları Dergisi, 3(4), 820832.

Alrawadieh, Z., ve Demirkol, Ş. (2015). Konaklama işletmelerinde e-şikâyet yönetimi: İstanbul'daki beş yıldızlı oteller üzerinde bir çalışma. Nişantaşı Üniversitesi Sosyal Bilimler Dergisi, 3(1), 130-148. 
Alrawadieh, Z., ve Law, R. (2019). Determinants of hotel guests' satisfaction from the perspective of online hotel reviewers. International Journal of Culture, Tourism and Hospitality Research, 13(1), 84-97.

$\mathrm{Au}$, N., Buhalis, D., ve Law, R. (2009). Complaints on the online environmentthe case of Hong Kong hotels. Information and communication technologies in tourism 2009, 73-85.

$\mathrm{Au}$, N., Buhalis, D., ve Law, R. (2014) Online Complaining Behavior in Mainland China Hotels: The Perception of Chinese and Non-Chinese Customers. International Journal of Hospitality $\mathcal{E}$ Tourism Administration, 15(3), 248-274.

Aydın İl Kültür ve Turizm Müdürlüğü (2020). Turizm Tesisleri. 29 Temmuz 2020 tarihinde https://aydin.ktb.gov.tr/Eklenti/69244,bakanlik-isletmebelgeli-ilcelere-gore-tesisler---site-.pdf?0 adresinden erişildi.

Barreda, A., ve Bilgihan, A. (2013). An analysis of user-generated content for hotel experiences. Journal of Hospitality and Tourism Technology, 4(3), 263280.

Behremen, C., Seçilmiş, C., ve Akın, M. (2017). Helâl konseptli konaklama işletmelerine yönelik yapılan online müşteri şikâyetleri üzerine bir araştırma: Halalbooking.com örneği. 1. International Halal Tourism Congress, 773-784. Alanya: Adenya Resorts Hotel \& Spa.

Booking (2020). Anasayfa. 29 Temmuz 2020 tarihinde https://www.booking.com/ adresinden erişildi.

Çetin Gürkan, G., ve Dönmez Polat, D. (2014). Ege ve Akdeniz Bölgesi'nde faaliyet gösteren resort konaklama işletmeleri hakkında yapılan şikayetler üzerine nitel bir araştırma. Seyahat ve Otel İşletmeciliği Dergisi, 11(2), 45-61.

Dinçer, M. Z. ve Alrawadieh, Z. (2017) Negative word of mouse in the Hotel Industry: A content analysis of online reviews on luxury hotels in Jordan. Journal of Hospitality Marketing $\mathcal{E}$ Management, 26:8, 785-804, doi: 10.1080/19368623.2017.1320258

Doğan, O., Karasakal, S., ve Demirel, A. (2019). Konaklama işletmelerine yönelik yapılan çevrimiçi şikayetlerin sosyal ağ analiziyle incelenmesi: Eskişehir örneği. 20. Ulusal Turizm Kongresi,. Eskişehir: Anadolu Üniversitesi. 547555

Doğan, S. (2017). Otellere yönelik yapılan puanlama ve çevrimiçi yorumların değerlendirilmesine ilişkin Aksaray ilinde bir araştırma. Aksaray Üniversitesi İktisadi ve İdari Bilimler Fakültesi Dergisi, 9(3), 27-36. 
Doğan, S., Sert, S., ve Tutan, E. (2016). Konaklama işletmeleriyle ilgili internet sitelerinde yer alan yorumların tüketici karar sürecine etkisi: Ankara'da Çalışan Öğretim Elemanları Üzerine Bir Araştırma. Uluslararası Yönetim Iktisat ve İsletme Dergisi, 12(30), 175-191.

Ercan, F. (2019). Sosyal medyada otel işletmelerine yönelik yorumların müşteri memnuniyeti ve memnuniyetsizliği açısından analizi. Selçuk Üniversitesi Sosyal Bilimler Meslek Yüksekokulu Dergisi, 22(2), 552-571.

Genç, K. ve Batman, O. (2018). Tarihi konak işletmelerine yönelik e-şikâyetlerin değerlendirilmesi: İpekyolu Ayaş-Sapanca koridoru üzerine bir araştırma. Uluslararası Yönetim İktisat ve İsletme Dergisi, 14(1), 283-296.

Gürbüz, E ve Ormankıran, G. (2020). Otel İşletmelerine ilişkin müşteri pozitif yorum ve şikayetlerinin yoğunlaştığı konulara ilişkin nitel bir değerlendirme. Journal of Applied Tourism Research, 1 (1), 17-32.

Holidaychack (2020). Anasayfa. 29 Temmuz 2020 tarihinde https://www.holidaycheck.de/ adresinden erişildi.

Lee, C. C. ve Hu, C. (2004). Analyzing hotel customers' ecomplaints from an internet complaint forum. Journal of Travel \& Tourism Marketing, 17(2-3), 167-181, doi: 10.1300/J073v17n02_13

Levy, S. E., Duan, W., ve Boo, S. (2013). An analysis of one-star online reviews and responses in the Washington, DC, lodging market. Cornell Hospitality Quarterly, 54(1), 49-63.

Memarzadeh, F. ve Chang, H. J. (2015) Online consumer complaints about southeast Asian Luxury Hotels. Journal of Hospitality Marketing $\mathcal{E}$ Management, 24(1), 76-98, doi: 10.1080/19368623.2014.893222

Özdemir, M. (2010). Nitel veri analizi: Sosyal bilimlerde yöntembilim sorunsalı üzerine bir çalışma. Eskişehir Osmangazi Üniversitesi Sosyal Bilimler Dergisi, 11(1), 323-343.

Özer Sarı, F., Alikılıç, Ö. ve Onat, F. (2013, March). E-complaining: Analysis of lodging customers'e-complaints from a Turkish Internet Website. International Conference on Information, Business and Education Technology (ICIBIT 2013), 561-565. Atlantis Press.

Özer Sarı, F., ve Aşman Alikılıç, Ö. (2016). How ready are the Turkish Hospitality and travel organizations for e-complaint handling?. AJIT-e: Online Academic Journal of Information Technology, 7(24), 75-94. doi: 10.5824/13091581.2016.3.005.x 
Şahin, B., Kazaoğlu, İ. H., ve Sönmez, B. (2017). Konaklama işletmelerine yönelik seyahat sitelerinde yer alan şikayetler üzerine bir inceleme: Bişkek örneği. MANAS Sosyal Araştırmalar Dergisi, 6(5), 163-177.

Şikayetvar (2020). Anasayfa. 29 Temmuz 2020 tarihinde https://www.sikayetvar.com/ adresinden erişildi.

Tripadvisor (2020). Anasayfa. 29 Temmuz 2020 tarihinde https://www.tripadvisor.com.tr/ adresinden erişildi.

Ünal, A. (2019). Otel müşterilerinin e-şikâyetlerinin sınıflandırılmasına yönelik bir çalışma. Uluslararası Yönetim İktisat ve İşletme Dergisi, 15(2), 561-581.

Zengin, B., ve Haliloğlu, S. (2020). Konaklama işletmelerine yönelik eşikâyetlerin incelenmesi: Sakarya örneği. Safran Kültür Ve Turizm Araştırmaları Dergisi, 3(2), 68-84.

Zheng, T., Youn, H. ve Kincaid, C. S. (2009). An analysis of customers' ecomplaints for Luxury Resort Properties. Journal of Hospitality Marketing $\mathcal{E}$ Management, 18(7), 718-729. doi: 10.1080/19368620903170240.

\section{Kaynakça Bilgisi / Citation Information}

Ayyıldız Yazıcı, A. ve Baykal, M. (2020). Otel işletmelerine yönelik eşikâyetlerin içerik analizi ile incelenmesi: Kuşadası 5 yıldızlı otel işletmeleri örneği. OPUS-Uluslararası Toplum Araştırmaları Dergisi, 16(30), 2659-2683. DOI: 10.26466/opus.785657 